\title{
Internal Colonialism, Alien Rule, and Famine in Ireland and Ukraine
}

\author{
Michael Hechter
}

Arizona State University

\begin{abstract}
The Irish famine of the mid nineteenth century and the Ukrainian famine of the twentieth century have been the subject of large and quite contentious literatures. Whereas many popular explanations of the Irish famine attribute it to the English government's infatuation with laissez-faire economic doctrines, by contrast the Ukrainian famine has often been ascribed to Stalin's resentment of Ukraine's resistance to the Soviet revolution. This essay suggests that despite their many differences, during these years both Ireland and Ukraine can be considered to have been internal colonies of their respective empires. The key implication of this conception is that these appalling famines arose from a common underlying cause: namely, the inferior political status of these regions relative to that of the core regions of these states. One of the defining characteristics of internal colonies is that they often suffer from alien rule. Alien rulers are typically indifferent to the welfare of the residents of the culturally distinctive regions within their borders. Due to this indifference, both the British and Soviet central rulers cast a blind eye to the fate of the Irish and Ukrainian peasants.
\end{abstract}

Keywords: Ireland, Ukraine, famine, internal colonialism, alien rule.

\footnotetext{
A lthough the differences between Ireland and Ukraine are vast, their histories have something important in common: both were once dependent peripheries in imperial states. An insular Celtic tribal society with an overwhelmingly Catholic population, Ireland was conquered in the seventeenth century by Oliver Cromwell. The Cromwellian Settlement expropriated much of Ireland's land, giving it to Cromwell's Protestant financiers and the soldiers of his New Model Army as recompense for their support in the English Civil War. Thereafter, England instituted the Penal Laws (not rescinded until 1829), which among other things denied Catholics many civil rights and prohibited them from holding office anywhere in Great Britain. As the great Irish political theorist Edmund Burke-a member of the Protestant Ascendancy_characterized them, these laws were "a machine of wise and elaborate contrivance, as well fitted for the oppression, impoverishment and degradation of a people, and the debasement in them of human nature itself, as ever proceeded from the perverted ingenuity of man" (Mitchel, The Last Conquest 10).
} 
Whereas modern Ireland had been governed by only one alien ruler, modern Ukraine was divided between the Habsburg and Russian Empires, and after 1917 suffered periods of German, Soviet (Russian), Polish, and Czechoslovakian control (von Hagen). Beyond the fact of subjection to alien rule, Ukraine shares other parallels with the Irish experience. For example, Ukrainian culture was disparaged, and the Ukrainian language was suppressed in Romanov Russia.

The experiences of Ireland and Ukraine also mirrored, in part, that of the Western European overseas colonies, while the characteristics of the colonies also diverged substantially. ${ }^{1}$ Each colony was geographically, culturally, and politically unique. Traditionally, the literature on colonial societies was built on the basis of ethnographic studies of the various cultural groups-or "tribes"-about which the colonial powers sought intelligence, the better to control them. Some of these ethnographies-by the likes of E. E. Evans-Pritchard, Bronisław Malinowski, and Alfred Radcliffe Brown-remain classics of modern social science.

Following arguments made after World War II by Max Gluckman and Georges Balandier, however, a new emphasis began to emerge in the postwar colonial literature, which stressed commonalities rather than differences (see Cooper 3-32). ${ }^{2}$ In Balandier's view, these territories all faced a set of conditions that he termed "the colonial situation," which consisted of the following:

- $\quad$ The domination imposed by a foreign minority, racially (or ethnically) and culturally different, acting in the name of a racial (or ethnic) and cultural superiority, dogmatically affirmed, and imposing itself on an indigenous population constituting a numerical majority but inferior to the dominant group from a material point of view;

- A domination linking radically different civilizations into some form of relationship;

- An industrialized society with a powerful economy and fast tempo of life imposing itself on a non-industrialized society with a "backward" economy in which the pace of living is much slower;

- The antagonistic relationship between these two societies resulting from the subservient role to which the colonial people are subjected as "instruments" of the colonial power; and

- The need, in maintaining this domination, to resort not only to force but also to a system of pseudo-justification and stereotyped behaviors. (54-55)

\footnotetext{
${ }^{1}$ In fact, this variation even occurred within each of the colonies (cf. Lawrence).

2 Somewhat later, the British colonial officer J. S. Furnivall popularized the concept of "the plural society," which he considered a necessary outcome of European overseas colonialism (see Lee for an introduction and discussion of the subsequent literature).
} 
More than two decades later, I published Internal Colonialism, a study of the roots of nationalism in the Celtic Fringe of the United Kingdom (Hechter). The book argued that many aspects of Balandier's colonial situation antedated the rise of many overseas colonies. Indeed, something quite analogous had happened to the culturally distinct peripheries of the metropoles themselves - such as the United Kingdom, France and Spain -in the course of state-building. Christian attempts to rid the Iberian Peninsula of Muslims and Jews, the Reconquistá, began in eighth-century Asturias and continued over the course of at least seven hundred years, culminating in the Spanish Inquisition. Just as England had conquered Wales in 1536, added Scotland with the Treaty of Union in 1707, and incorporated Ireland in 1801, the Île de France had gradually extended its rule into Burgundy, Occitania, and Brittany over the centuries. For many Western European countries, state building necessarily entailed internal colonialism (see Bartlett for other European examples). ${ }^{3}$

I did not invent the term "internal colonialism": its earliest use was by Russian populists to describe the exploitation of peasants by urban classes. Later it was adopted by Antonio Gramsci, Vladimir Lenin, Ievgenii Preobrazhenskii, and Nikolai Bukharin to characterize the persisting underdevelopment of certain Russian and Italian regions. This usage was even more capacious than my own because it concerned the expansion of central state capacity into peripheral regions that shared a common culture with the core. In contrast, I reserved the term for states that extended their control over culturally distinct peripheries.

What then does the internal colonial situation consist of? Internal Colonialism presented two separate but related arguments (Hechter). The first, which is the focus of this paper, was couched at the level of regions. This argument holds that the lack of political sovereignty characteristic of internal colonies limited their economic welfare and threatened their cultural integrity. Whereas many internal colonies have been economically disadvantaged, there are exceptions such as Scotland and Catalonia, two territories that have been economically advanced. Nonetheless, even economically advanced peripheries can be considered internal colonies when the policies that govern these territories are decided in a larger political arena, one in which the periphery is destined to play only a minor role at best. The peripheral population, therefore, is denied the privilege and responsibility of determining its own political fate.

The second argument, an elaboration on one of the themes highlighted by Balandier, focused on individuals rather than regions and holds that

3 Likewise, Perdue can be read as the story of the establishment of internal colonialism in China, as the Qing Dynasty-ironically, ethnically Manchu rather than Han-extended its rule westward to Xingiang. See also Biran. 
culturally distinct identities remain salient among the members of groups that are subject to a cultural division of labour, regardless of increased interregional contact or industrialization. Due to the scarcity of data on the stratification of cultural groups, there was very little empirical support for this argument (my article on the cultural division of labour was an exception [Hechter, "Group Formation"]), but happily that situation recently has changed. New empirical analyses of inter-group conflict and civil war (some carried out under the rubric of "horizontal inequalities") have lent considerable support to the argument (see Stewart; Cederman et al.; Siroky and Hechter, "Ethnicity, Class, and Civil War").

In addition to the Celtic Fringe, which was the focus of Internal Colonialism, this type of analysis has been applied, at least informally, to a variety of cases (Stone), including Brittany (Reece) and Corsica in France (Siroky et al., "Containing Nationalism"); Estonia (Mettam and Williams) and Central Asia (Loring) in the USSR; Xingiang in China (Gladney; see also Sautman for a skeptical view); Quebec in Canada (McRoberts; Pettinicchio); Catalonia in Spain (McPhee); Palestine in Israel (Zureik); Alaska (Dryzek and Young), Native American reservations (Palmer and Rundstrom) and Appalachia in the USA (Lewis et al.); the Central Highlands of Vietnam (Evans); and the Torres Strait Islands in Australia and Eastern Viti Levu in Fiji (Durutalo). The argument as a whole fits some of these cases better than others (Hind; Chávez; Hechter, "Internal Colonialism Revisited").

In the remainder of this essay I will consider whether the internal colonial thesis can shed any light on two of the defining events in modern Irish and Ukrainian history: their famines. I make no claim to contribute to the large and contentious historiography on the causes of these disasters, but I do want to suggest that alien rule, a defining attribute of the internal colonial theory, is at least partially responsible for them.

Ireland's status as an internal colony played a critical role in the Great Famine of 1845-50. Whereas the ostensible culprit in the Irish famine was the arrival of potato blight ("Phytophthora infestans") to the British Isles and the Continent, the actual causes of the famine are a good deal more complicated. The key factor affecting the food supply was the extreme dependence of the Irish peasantry on the potato (Ó Gráda, The Great Irish Famine). This dependence, in turn, was exacerbated by the small size of Irish peasant plots. ${ }^{4}$ The potato was the only subsistence crop that could be produced in the peasants' miniscule plots. The arrival of blight effectively destroyed the main food supply for millions of Irish peasants, but this did not necessarily cause starvation. Ireland was a major producer of grain and

\footnotetext{
4 The extreme inequality in Irish landholding has its own history, one that I cannot rehearse here (see Solow).
} 
beef for the British market, and the British government could have acted to divert some of the food destined for export, but it did not.

The reasons why the government failed to alleviate the suffering of the Irish peasants remain the subject of vigorous and partisan controversy. ${ }^{5}$ Among the factors that have been held responsible for the failure to relieve starvation are the hegemony of economic liberalism (laissez-faire) in England, which inveighed against nearly any government interference in commodity and labour markets; the pervasive anti-Irish racism of the British elite; ${ }^{6}$ and fear of Irish nationalism, which previously had encouraged Britain's continental enemies to plan to invade Ireland and use it as a beachhead for a subsequent invasion of Britain. ${ }^{7}$

Just as in the Irish case, there is a good deal of debate about the causes of the Holodomor (the 1932-33 Famine in Ukraine). What is not in doubt, however, is that no biological agent was involved; the famine was an entirely man-made affair caused by official Soviet policy (Plokhy 254). Some Ukrainian writers view it as a genocide instituted by Stalin to punish Ukrainians for anti-Soviet, counter-revolutionary, and nationalist sentiments, whereas others believe that rather than targeted at Ukraine, the Famine was a result of policies designed to maximize grain production for export throughout the USSR and beyond in order to finance rapid industrialization. More specifically, several factors have been suggested as causes of the 1932-33 Famine:

\footnotetext{
${ }^{5}$ At the same time, it is important not to underestimate the challenges that the potato famine posed to the English rulers: "To have met the potato famine with anything like a complete success would have been a Herculean task for any government. The total failure of the food of a nation was ... a fact new in history; such being the case, no machinery existed extensive enough to neutralize its effects, nor was there extant any plan upon which such machinery could be modeled. Great allowance must be therefore made for the shortcomings of the Government, in a crisis so new and so terrible; but after making the most liberal concessions on this head, it must be admitted that Lord John Russell and his colleagues were painfully unequal to the situation. They either could not or would not use all the appliances within their reach, to save the Irish people" (O'Rourke 65).

6 Thus, the nineteenth-century Cambridge historian Charles Kingsley commented in a letter dated 4 July 1860, on his trip to Ireland: "But I am haunted by the human chimpanzees I saw along that hundred miles of horrible country. I don't believe they are our fault. I believe there are not only many more of them than of old, but they are happier, better, more comfortably fed and lodged under our rule than they ever were. But to see white chimpanzees is dreadful: if they were black, one would not feel it so much, but their skins, except where tanned by exposure, are as white as ours" (Curtis 84).

${ }^{7}$ However, by midcentury the fear of a continental invasion had receded; otherwise, as argued later in this essay, it might have spurred more compassionate policies.
} 
- The rapid introduction of collectivization in Ukraine compared to other regions;

- The high grain quotas placed upon Ukraine;

- The closure of the borders of Ukraine and the North Caucasus to prevent the migration of starving peasants;

- Moscow's unresponsiveness to information concerning the imminence of famine provided by Ukrainian officials in 1932;

- Stalin's suspicions of the Ukrainian peasantry and his fear of "losing Ukraine";

- Draconian measures taken by the Extraordinary Commission in Ukraine in 1932, confiscating grain as well as meat and vegetables, thereby contributing to a food shortage;

- The relative absence of starvation in Russia and Belarus; and

- The assault on the Ukrainian nation, indicated by terror and deportations, the purge of cultural and national leaders, and the cessation of the policy of Ukrainization. (Marples 36)

I have neither the competence nor the inclination to weigh in on debates about whether the Holodomor qualifies as a genocide. What is indisputable in the case of both famines, however, is that the policies of both core states led to continued export from these food-producing regions rather than diversion of food to their starving peasants. This outcome is fully in line with Amartya Sen's influential analysis of the general causes of famine. For Sen, the ultimate causes of famines lie not in the insufficiency of food in a given territory but in the "entitlements" that affect its distribution. Sen regards each individual in the economy as having an endowment consisting of land, labour, and other resources. Each bundle of resources can be transformed into a set of entitlements via exchange. Starvation happens when individuals cannot command the commodity bundles that could keep them alive. ${ }^{8}$ This can occur when their endowment collapses (due, for example, to the potato blight in Ireland or to the state's requisitioning of grain and other staples in the USSR), or when the value of their product falls precipitously. For Sen, therefore, the ultimate causes of famine are intrinsically social and political.

In a study of a number of Victorian famines associated with the onset of El Niňo conditions, Mike Davis likewise concludes that social and political factors were responsible for famine rather than destructive environmental shocks that hamper food production. For Davis, the real culprits in these environmentally induced famines were capitalists in thrall to the liberal

\footnotetext{
${ }^{8}$ In market economies, such as nineteenth-century Ireland, individuals' exchange entitlements included (1) their ability to find employment (at a given wage and length of time); (2) their ability to sell their non-labour assets; (3) what they could produce from their own labour power and endowments; (4) the cost of attaining resources and the value of the products they could sell; (5) the welfare benefits they were entitled to, and (6) the taxes they had to pay.
} 
doctrines of laissez-faire. In his view, these powerful actors were fanatically opposed to state policies that might have distributed food to the starving, preferring to let the invisible hand have its way-a position not so dissimilar to that currently held by many Republican legislators in the United States with respect to health care, among other issues.

The fly in the ointment, however, is that the great famines of the twentieth century - the Holodomor and other Soviet famines, the 1958-61 famine in Maoist China, Cambodian starvation in the 1970s, and the continuing death from hunger in North Korea-have occurred in command economies, not liberal capitalist ones (Carney). If famines have occurred under both liberal capitalist and state socialist regimes, then neither of these ideologies can be either necessary or sufficient to cause famine. This is not to deny the obvious point that in each case, ideology was used to justify, if not to initiate, the policies that led to starvation. In the Irish case, blaming the popularity of laissez-faire for the state's refusal to intervene in the market is an old trope that was first enunciated in John Mitchel's The Last Conquest of Ireland (Perhaps), published in 1860, and later by James Connolly, the principal theorist of Irish nationalism and one of the victims of the Easter Rising. ${ }^{9}$ In the USSR, both Stalin's (ostensibly Marxian) commitment to the collectivization of agriculture and his desire to punish what he considered to be the counter-revolutionary Ukrainians have been presented as justifications for the harsh Soviet policies. ${ }^{10}$

Despite the continuing controversies about the causes of these two famines-much of it politically motivated ${ }^{11}$ - the hard truth is that in both

\footnotetext{
${ }^{9}$ Whereas Connolly's views derived from a Marxist analysis, Mitchel's were animated by antipathy to liberalism in all its forms. After escaping to the USA to avoid arrest in Ireland, Mitchel became a strong advocate of the Confederacy and a defender of slavery.

10 "Soviets, among them also the Soviets in the national republics, held the real executive power in their hands and linked the party to state apparatus. As long as the Kremlin had full control over these institutions there was no danger of the disintegration of the Soviet Union. If this control were to shift to the regional structures of the Party, for example in case of a crisis in the center, then this threat would become very real indeed. On the grounds of that strong national (non-Soviet) inclination towards traditions of statehood, the Kremlin judged Ukraine to pose the greatest risk" (Kulchytskyi 28).

11 Some of the politicization is evident in memorials to the famines. Little notice was taken of the centenary of the Irish famine in 1945. "Ireland in 1945 was a country of ration books, looking anxiously at European neighbours menaced by food shortage. It was no time to expend resources on memorialising Famine. By 1995 Ireland was at possibly the most energizing stage of an upward economic trajectory, the eventual unhappy downturn of which was more than a decade away. Ironically, this brave new Ireland was founded on the embrace of an economic strategy that was a latter-day
} 
cases, alien rulers in London and Moscow refused to suspend the export of grain and other foodstuffs and supply it to starving farmers in culturally distinct peripheries. ${ }^{12}$ United Kingdom Prime Minister Tony Blair admitted as much in his 1997 apology to the Irish people:

That one million people should have died in what was then part of the richest and most powerful nation in the world is something that still causes pain as we reflect on it today. Those who governed in London at the time failed their people through standing by while a crop failure turned into a massive human tragedy. As a consequence, these famines led to massive loss of life and widespread emigration. (Marks)

One implication that can be drawn from these histories is that had Ireland and Ukraine been self-governing rather than subject to alien rule, their political leaders might have taken more steps to relieve the suffering. Unlike alien rulers, native ones generally have greater incentives to be responsive to the grievances of their constituents. In both London and Moscow there was not much sympathy for the fate of the ethnically and linguistically distinct Irish and Ukrainians, and neither periphery had the political capacity required to exercise decisive influence in their respective cores.

The modifier "might" in the preceding paragraph expresses an important caveat, however. Native rulers may be more motivated to alleviate famine and stimulate peripheral economic growth than their alien counterparts, but their capacity to do so hinges on the actual policies that they enact. If they adopt unsuitable or ill-advised policies, they may do no better than some alien rulers and might even do worse. Take Ireland, for example. Although the leaders of the newly formed Republic clearly sought to promote economic growth following independence in 1922, their antipathy to free trade and foreign direct investment hampered their ability to deliver it. Only after the government liberalized trade and investment policies in the 1990s - a full seven decades after the birth of the Republicdid Irish economic fortunes begin to shoot up (Ó Gráda, A Rocky Road).

Rather than viewing these two famines as solely the outcome of ideological commitments to economic liberalism or the malevolent ill will of core state rulers like Stalin, they can also be regarded as tragic by-products of alien rule. There is an overwhelming scholarly consensus that in the best of circumstances alien rule promotes indifference about the welfare of

mutant of the political economy once excoriated for turning the failure of the potato crop in the 1840s into a famine. There was little advertence to this irony" (Comerford 67).

12 Unlike the British state, the USSR did provide some food relief to Ukraine, but it was far from sufficient to prevent mass starvation (Kulchytskyi 28). 
members of peripheral groups; more frequently, it is nakedly exploitative. The reason for alien rulers' exploitative policies lies in their motivations to control or annex these territories in the first place. No one seriously believes that these motivations are altruistic (despite high-flown justifications like the famous French mission civilisatrice). Whatever they may say, alien rulers never seek to control or annex territories to make life better for their culturally distinct inhabitants. Instead, they do so for their own instrumental purposes: to help prop up their regimes, to loot resources of land and labour, to provide foodstuffs for their core populations, to open markets for their goods, to foster military expansionism, to increase security, and so forth. Since the whole point of alien rule is to profit the core regime, it can be no surprise that alien rulers could care less about providing good governance to the populations they have expended blood and treasure to conquer. ${ }^{13}$

Yet the historical record also reveals that in a minority of cases alien rulers do manage to provide good governance to their subjects (Hechter, Alien Rule). The Genoese Republic's podesteria resolved incipient inter-clan conflict and delivered substantially higher economic growth to the city-state for over a century. Similarly, the Chinese Maritime Customs Service (CMCS), a proto-state providing a panoply of public goods in China, propped up a shaky Qing regime and the subsequent republic from the mid-nineteenth century to 1949. Lavish American aid and counsel during the postwar occupations of Japan and Germany helped to establish successful and prosperous democracies in these two countries. Finally, as the recent demonstrations against Beijing's interference in the politics of Hong Kong reveal, many people in Hong Kong would prefer alien rule by the British to native rule by Beijing.

If alien rule can have such variable effects, then it is crucial to understand the conditions under which it promotes favourable outcomes. Since this is a question that has hardly ever been asked before, few studies bear upon it. My starting point is to assume that a good part of the answer lies in what the economists refer to as incentive compatibility. A policy is incentive compatible if each party can attain their best outcome merely by acting on the basis of their own true preferences. With respect to coreperiphery interaction, the simplest implication is that an optimal policy is one that promotes the welfare of both parties.

At a first approximation, welfare in this sense encapsulates all the stateprovided public goods desired by the inhabitants of each region. Take public education as an example of one relevant domain. Whereas residents of the core prefer their children to be educated in the dominant language (English in the United Kingdom; Russian in Ukraine), residents of the periphery may

13 And their efforts to profit from their colonies extended to all sectors of economic life, including the manipulation of currency systems (Narsey). 
prefer education in their native language (Gaelic in Ireland, Ukrainian in Ukraine). An incentive-compatible policy in this realm, therefore, would give to each region the kind of language instruction that its inhabitants prefer. This outcome is likely to occur when fair and effective governance in the periphery also promotes the welfare of rulers in the core.

This raises an obvious question: when do alien rulers profit from promoting good governance in the periphery? Two evident benefits are security and economic growth. If a peripheral territory is valuable to the core and can credibly threaten to secede from it, then cores have an incentive to make concessions - such as enacting good governance-to keep it in the fold (Siroky et al., "Center-Periphery"; Dzutsati). ${ }^{14}$ Likewise, if providing good governance in the periphery enhances core economic development, then this will also motivate core rulers to promote peripheral welfare. Absent these kinds of inducements, alien rulers have little reason to govern the periphery either effectively or fairly.

What implications does this analysis have for understanding the Irish and Ukrainian famines? Since internal colonies are potential sites for the development of secessionist movements, central authorities are likely to adopt more repressive policies in the periphery than in the core of the state. During the Napoleonic Wars, the British government dreaded the prospect of a French invasion of Ireland-and the French indeed had mounted unsuccessful invasions in 1796 and 1798 to support the rebellious United Irishmen-but by the mid-nineteenth century this concern had waned. In 1932 Stalin, however, did express fear that Ukraine might be ripe for secession, and this might have exacerbated Soviet policy in the Holodomor (Klid and Motyl 239-40). Yet each of these peripheries continued to produce grain and other critical foodstuffs for their alien rulers despite the massive starvation and social dislocation faced by their inhabitants. As a result, both alien rulers could ignore the massive human costs of their policies with relative impunity.

And so they did.

\footnotetext{
${ }^{14}$ In general, rulers are likely to offer concessions that increase local autonomy to territories under their control in circumstances where both parties profit. This form of control goes under the umbrella term of "indirect rule" (Mamdani; Hechter, Containing Nationalism; Gerring et al.; Naseemullah and Staniland; Siroky et al., "Containing Nationalism"). This principle even came into play during Nazi rule in occupied Europe. In Denmark, for example, the Germans struck a co-operative agreement that allowed the Danes to retain their own government in return for access to Danish food production, airfields, and other goods. This desire to maintain a low-cost form of occupation was largely responsible for saving the lives of a huge proportion of the Danish Jewish population, even after Hitler demanded that they be sent to concentration camps (Lidegaard; see also Futselaar).
} 
Works Cited

Balandier, Georges. "The Colonial Situation: A Theoretical Approach.” Social Change: The Colonial Situation, edited by I. Wallerstein, John Wiley \& Sons, 1966, pp. 3461.

Bartlett, Robert. The Making of Europe: Conquest, Colonization and Cultural Change, 950-1350. Penguin, 1994.

Biran, Michal. "Periods of Non-Han Rule." A Companion to Chinese History, edited by Michael Szonyi, Wiley Blackwell, 2017, pp. 129-42. Wiley-Blackwell Companions to History.

Carney, Judith A. Review of Late Victorian Holocausts, by Mike Davis. Annals of the Association of American Geographers, vol. 92, no. 1, 2002, pp. 173-75.

Cederman, Lars-Erik, et al. Inequality, Grievances, and Civil War. Cambridge UP, 2013.

Chávez, John R. "Aliens in Their Native Lands: The Persistence of Internal Colonial Theory." Journal of World History, vol. 22, no. 4, 2011, pp. 785-809.

Comerford, Vincent. "Grievance, Scourge or Shame? The Complexity of Attitudes to Ireland's Great Famine." Holodomor and Gorta Mór: Histories, Memories and Representations of Famine in Ukraine and Ireland, edited by Christian Noack et al., Anthem Press, 2012, pp. 51-73.

Connolly, James. Labour in Irish History. Andesite Press, 2017.

Cooper, Frederick. Colonialism in Question: Theory, Knowledge, History. California UP, 2005.

Curtis, L. Perry Jr. Anglo-Saxons and Celts: A Study of Anti-Irish Prejudice in Victorian England. Conference on British Studies at the University of Bridgeport, distributed by New York UP, 1968. Studies in British History and Culture 2.

Davis, Mike. Late Victorian Holocausts: El Niño Famines and the Making of the Third World. Verso, 2001.

Dryzek, John, and Oran Young. "Internal Colonialism in the Circumpolar North: The Case of Alaska." Development and Change, vol. 16, no. 1, 1985, pp. 123-45. DOI: 10.1111/j.1467-7660.1985.tb00204.x

Durutalo, Simione. Internal Colonialism and Unequal Regional Development: The Case of Western Viti Levu, Fiji. 1985. The University of the South Pacific, PhD dissertation.

Dzutsati, Valery. Divide and Retreat: Redistribution, Cultural Differences, and International Security as Determinants of Secessionist Violence. 2017. Arizona State University, PhD dissertation.

Evans, Grant. "Internal Colonialism in the Central Highlands of Vietnam." Sojourn: Journal of Social Issues in Southeast Asia, vol. 7, no. 2, 1992, pp. 274-304.

Futselaar, Ralf. Lard, Lice, and Longevity: The Standard of Living in Occupied Denmark and the Netherlands, 1940-1945. Aksant, 2008.

Gerring, John, et al. "An Institutional Theory of Direct and Indirect Rule." World Politics, vol. 63, no. 3, 2011, pp. 377-433. DOI: 10.1017/S0043887111000104

Gladney, Dru C. "Internal Colonialism and the Uyghur Nationality: Chinese Nationalism and Its Subaltern Subjects." Cahiers d'Études sur la Méditerranée Orientale et le Monde Turco-Iranien, vol. 25, 1998, http://journals.openedition.org/cemoti/48. DOI: 10.4000/cemoti.48 
Gluckman, Max. “Malinowski's 'Functional' Analysis of Social Change.” Social Change: The Colonial Situation, edited by I. Wallerstein, John Wiley \& Sons, 1966, pp. 25-33.

Hechter, Michael. Alien Rule. Cambridge UP, 2013.

---. Containing Nationalism. Oxford UP, 2000.

---. "Group Formation and the Cultural Division of Labor." American Journal of Sociology, vol. 84, no. 2, 1978, pp. 293-318. DOI: 10.1086/226785

---. Internal Colonialism: The Celtic Fringe in British National Development, 1536-1966. U of California P, 1975.

---. "Internal Colonialism Revisited." New Nationalisms of the Developed West: Toward Explanation, edited by Edward A. Tiryakian and Ronald Rogowski, George Allen \& Unwin, 1985, pp. 17-26.

Hind, Robert J. "The Internal Colonial Concept." Comparative Studies in Society and History, vol. 26, no. 3, 1984, pp. 543-68. DOI: 10.1017/S0010417500011130

Klid, Bohdan, and Alexander J. Motyl. The Holomodor Reader: A Sourcebook on the Famine of 1932-1933 in Ukraine. Canadian Institute of Ukrainian Studies P, 2012.

Kulchytskyi, Stanislav V. "Holodomor in Ukraine 1932-1933: An Interpretation of Facts." Holodomor and Gorta Mór: Histories, Memories and Representations of Famine in Ukraine and Ireland, edited by Christian Noack et al., Anthem Press, 2012, pp. 19-34.

Lawrence, Adria. Imperial Rule and the Politics of Nationalism: Anti-Colonial Protest in the French Empire. Cambridge UP, 2014.

Lee, Hock Guan. "Furnivall's Plural Society and Leach's Political Systems of Highland Burma." Sojourn: Journal of Social Issues in Southeast Asia, vol. 24, no. 1, 2009, pp. 32-46. DOI: 10.1355/sj24-1c

Lewis, Helen Matthews, et al. Colonialism in Modern America: The Appalachian Case. Appalachian Consortium Press, 1978.

Lidegaard, Bo. Countrymen: The Untold Story of How Denmark's Jews Escaped the Nazis, of the Courage of Their Fellow Danes-and of the Extraordinary Role of the SS. Translated from Danish by Robert Maass, Alfred A. Knopf, 2013.

Loring, Benjamin. "'Colonizers with Party Cards': Soviet Internal Colonialism in Central Asia." Kritika: Explorations in Russian and Eurasian History, vol. 15, no. 1, 2014, pp. 77-102. DOI: $10.1353 / \mathrm{kri} .2014 .0012$

Mamdani, Mahmood. Citizen and Subject: Contemporary Africa and the Legacy of Colonialism. Princeton UP, 1996.

Marks, Kathie. "Blair Issues Apology for Irish Potato Famine." The Independent, 2 June 1997.

Marples, David R. "Ethnic Issues in the Famine of 1932-1933 in Ukraine." Holodomor and Gorta Mór: Histories, Memories and Representations of Famine in Ukraine and Ireland, edited by Christian Noack et al., Anthem Press, 2012, pp. 35-50.

McPhee, Peter. "A Case-Study of Internal Colonization: The Francisation of Northern Catalonia." Review, vol. 3, no. 3, 1980, pp. 398-428.

McRoberts, Kenneth. Quebec: Social Change and Political Crisis. McClelland and Stewart, 1980.

Mettam, Colin W., and Stephen Wyn Williams. "Internal Colonialism and Cultural Divisions of Labour in the Soviet Republic of Estonia." Nations and Nationalism, vol. 4, 1998, pp. 363-88. DOI: 10.1111/j.1354-5078.1998.00363.x

Mitchel, John. Jail Journal. The Citizen, 1854. 
---. The Last Conquest of Ireland (Perhaps). Edited by Patrick Maume, U College Dublin $\mathrm{P}, 2005$.

Narsey, Wadan. British Imperialism and the Making of Colonial Currency Systems. Palgrave Macmillan, 2016.

Naseemullah, A., and P. Staniland. "Indirect Rule and Varieties of Governance." Governance: An International Journal of Policy, Administration, and Institutions, vol. 29, no. 1, 2016, pp. 13-30. DOI: 10.1111/gove.12129

Ó Gráda, Cormac. The Great Irish Famine. Macmillan, 1989.

---. A Rocky Road: The Irish Economy since the 1920s. Manchester UP, 1997.

0'Rourke, John. The History of the Great Irish Famine of 1847, with Notices of Earlier Irish Famines. McGlashan and Gill / James Duffy and Sons, 1875.

Palmer, Mark, and Robert Rundstrom. "GIS, Internal Colonialism, and the US Bureau of Indian Affairs." Annals of the Association of American Geographers, vol. 103, no. 5, 2013, pp. 1142-59. DOI: 10.1080/00045608.2012.720233

Perdue, Peter C. China Marches West: The Qing Conquest of Central Eurasia. Belknap Press, 2005.

Pettinicchio, David. "Migration and Ethnic Nationalism: Anglophone Exit and the 'Decolonisation' of Québec.” Nations and Nationalism, vol. 18, no. 4, 2012, pp. 719-43. DOI: 10.1111/j.1469-8129.2011.00513.x

Plokhy, Serhii. The Gates of Europe: A History of Ukraine. Basic Books, 2015.

Reece, J. "Internal Colonialism: The Case of Brittany." Ethnic and Racial Studies, vol. 2, no. 3, 1979, pp. 275-92. DOI: 10.1080/01419870.1979.9993269

Sautman, Barry. "Is Xingiang an Internal Colony?" Inner Asia, vol. 2, no. 2, 2000, pp. 239-71.

Sen, Amartya. Poverty and Famines: An Essay on Entitlement and Deprivation. Cambridge UP, 1981.

Siroky, David S., et al. "Center-Periphery Bargaining in the Age of Democracy." Swiss Political Science Review, vol. 22, no. 4, 2016, pp. 439-53. DOI: 10.1111/spsr.12235

Siroky, David S. et al. "Containing Nationalism: Culture, Economics and Indirect Rule in Corsica," Comparative Political Studies, 2020. DOI: 10.1177/0010414020957671

Siroky, David S., and Michael Hechter. "Ethnicity, Class, and Civil War: The Role of Hierarchy, Segmentation, and Cross-Cutting Cleavages." Civil Wars, vol. 18, no. 1, 2016, pp. 91-107. DOI: 10.1080/13698249.2016.1145178

Solow, Barbara. The Land Question and the Irish Economy. Harvard UP, 1971.

Stewart, Frances. Horizontal Inequalities and Conflict: Understanding Group Violence in Multiethnic Societies. Palgrave, 2008.

Stone, John, editor. Internal Colonialism in Comparative Perspective. Special issue of Ethnic and Racial Studies, vol. 2, no. 3, 1979.

von Hagen, Mark. War in a European Borderland: Occupations and Occupation Plans in Galicia and Ukraine, 1914-1918. Washington UP, 2007. Donald W. Treadgold Studies on Russia, East Europe, and Central Asia.

Zureik, Elia T. The Palestinians in Israel: A Study in Internal Colonialism. Routledge \& Kegan Paul, 1979. 